\title{
KODEVEKSLING I NETTDISKURS I NORGE
}

Hovedmålsettingen med denne forskningsstudien er å undersøke begrepet kodeveksling og måten den manifesterer seg på innen nettkommunikasjon i Norge, fortrinnsvis i kontekst av sosiale medier. Problemstillingen tar utgangspunkt $i$ at nettdiskurs er enda et domene der norsk sakte men sikkert taper terreng til fordel for engelsk som har stadig større innflytelseskraft som lingua franca. Oppgavens primære fokus er dermed rettet mot kodeveksling for språkparet, norsk og engelsk hos norske språkbrukere på de mest populære nettsamfunn i Norge. Kodevekslingens relevans, kompleksitet og funksjoner er analysert innenfor teoretisk og metodologisk rammeverk av kontaktlingvistikk med særlig henblikk på hovedårsaker som fører til dens forekomst innenfor den norske nettdiskursen. I den sammenheng er det belyst de mest påfallende bruksmønstrene så vel som stilistiske effekter som gjør seg mest gjeldende som følge av spesifikt språkvalg og språkbruk av norsk og engelsk.

Nøkkelord: kodeveksling, Norge, sosiale medier, engelsk, nettdiskurs.

\section{Innledning}

Samspill av flere ulike faktorer som globalisering og internasjonalisering etterfulgt av engelsk som bindemiddel har bidratt til at stadig flere folk og språk (varieteter) kommer i kontakt gjennom verdensvev. Allerede på slutten av 20. århundret var det ingen tvil om at det store gjennombruddet av internett ville virke som katalysator for ytterligere spredning av nyoppdagete kommunikasjonsmidler men først og fremst utvidelse av eksisterende kommunikasjonsarenaer.

Sett i forhold til den framvoksende digitale revolusjonen med eksploderende bruk av nye informasjonsteknologier ved inngangen av 21. århundre, står Norge i en særstilling grunnet rekordhøy internett-trafikk. Rettere bestemt, ligger Norge intet mindre enn på verdenstoppen tatt $\mathrm{i}$ betraktning at hele $98 \%$ av befolkningen

\footnotetext{
* Univerzitet u Beogradu, Filološki fakultet, Studentski trg 3, 11000 Beograd; jovana.vurdelja@gmail.com
} 
bruker internett på daglig basis (Datareportal 2020). Samtidig tyder disse skyhøye tallene på en utvilsom sammenheng med et hyppig bruk av sosiale medier, ettersom så mye som $70 \%$ av befolkningen tilbringer flere timer om dagen på sosiale nettsamfunn, hvorav Facebook er desidert den mest populære, fulgt av Snapchat, Instagram, Linkedln og Twitter (Ipsos SoMe tracker Q3'21).

Med utgangspunkt $i$ at internett hadde etablert seg som et av de mest dominerende kommunikasjonsmedier i Norge og dermed framkalt atskillig større bruk av e-poster, direkte meldingstjenester, diskusjonsforum, chatt, virtuelle undervisninger på skoler og universiteter men ikke minst sosiale medier, har det teknologiske paradigmeskiftet vist seg å være banebrytende i forhold til både nye arenaer og måter å kommunisere på.

I et sånt klima preget av raskt voksende teknologiske nyvinninger, blir framvekst av en særegen nettbasert kommunikasjon sett på som et nytt imperativ i den digitale hverdagen. Ut ifra et lingvistisk aspekt, er en av hovedimplikasjoner som er nært korrelert til økt bruk av sosiale medier forekomst av kodeveksling samt tilblivelse av et nytt språkfenomen, dvs. datamediert kommunikasjon eller Computer Mediated Communication (CMC), rettere bestemt Netspeak. Begrepet Netspeak ble først introdusert av den britiske lingvist David Crystal med formålet om å henlede oppmerksomhet på et språk som er uatskillig knyttet til internett og skjelnes betraktelig fra offline språkbruk. Han beskrev netspeak som språkvarietet:

Displaying features that are unique to the Internet, arising out of its character as a medium which is electronic, global, and interactive. Variably dubbed a language variety or even a new linguistic medium netspeak is divided into sub-varieties that are related to different communication modes. For instance, the language of e-mails comprises functionally distinct elements that are central for the identification of e-mail as a linguistic variety, such as headers, signatures, greetings and responsive quotations, as well as more local points of stylistic significance, for instance, spelling variation (Crystal ifølge Androutsopoulos, 2006: 420)

Fenomenet ble ytterligere utdypet av den amerikanske lingvist Susan Herring som har primært fokusert på diskursanalyse av CMC paradigmet i kontekst av kjønnsroller og kjønnsforskjeller i forhold til internett og språkbruk som hun klargjorde i studiene Computer-Mediated Communication, Gender differences in CMC: Findings and implications Computer-mediated discourse analysis: An approach to researching online communities. Blant forskere som har fordypet seg i CMC-netspeak er også den britiske Naomi Baron som brakte to lingvistiske kjennetegn av CMC på bane: emotikoner (smilefjes, emojier) og flaming. 
I den kontekst dukker det opp et av de mest merkelsesverdige trekkene som nettkommunikasjon bærer preg av, fenomenet kodeveksling, der språkbrukere alternerer dvs. skifter mellom to eller flere språk eller varieteter i en og samme samtale. Ifølge Jannis Androutsopoulos kodeveksling i internettkommunikasjon er et felt som er relevant for innsikt i felt som pragmatikk, sosiolingvistikk og diskursstudier (Androutsopoulos ifølge Grøvli 2013: 24).

I den sammenheng har jeg lagt fram en hypotese om at norske språkbrukere har en påfallende tendens til å låne, veksle og mikse ordene innen datamediert kommunikasjon med en klar hensikt for enten å fremme forståelse eller eventuelt unngå mulige misforståelser. Teoretisk er studien forankret i kontaktlingvistikk og tar sikte på å belyse både omfang, formål så vel som sammenheng der kodeveksling på norske sosiale medier som oftest forekommer i tillegg til underliggende årsaker som trigger den alterneringen mellom norsk og engelsk. Den empiriske delen av studien utgjør et utvalg av skriftlig kommunikasjon hentet ifra Facebook, Twitter og Instagram blant norske språkbrukere i en alder av 22-60 år. Med å analysere språkvalg og språkbruk blant flerspråklige nordmenn blir det belyst kommunikative funksjoner av kodeveksling i denne bestemte konteksten sett i lyset av deres bruk som pragmatiske eller stilistiske virkemidler.

\section{Språk i kontakt}

Den akselerende globalisering og internasjonalisering som mesteparten av kloden har undergått i forrykende tempo de siste tiårene, har medført etablering av teknologisk avanserte arenaer som muliggjør både reell og virtuell kommunikasjon med utgangspunkt i vidt forskjellig språkbruk. Med andre ord, denne virkelige og digitale nettverksbygging som har tjent blant annet som brobygging i henhold til språklig mangfold på globalt nivå, har gitt seg utslag på mange ulike måter, der det mest påfallende utfallet innebærer språkblanding av ulik art.

Sånn sett kan den ovenfor nevnte språkblandingen ansees som et lingvistisk fenomen som oppstår som direkte og uunngåelig konsekvens av at to eller flere språk kommer i kontakt, og dermed øver innflytelse på hverandre. I den sammenheng, tolkes ikke språkkontakt som et begrep som er forbeholdt noen bestemte, isolerte grupper eller miljø men kan tvert imot forekomme på alle nivå: på individnivå, gruppenivå så vel som samfunnsnivå og gjerne refererer til både kontakt mellom ulike språk eller ulike varieteter innenfor ett og samme språk. I en sånn språksituasjon, der et sosiopolitisk klima innenfor mange 
europeiske og verdens samfunn hovedsakelig er kjennetegnet av sameksistens av flerkulturalisme og flerspråklighet, overgangen fra det monolingvale til det multilingvale samfunnet der folk og språk kommer i stadig større kontakt, har hatt en rekke lingvistiske implikasjoner med betydelige innvirkninger på språkendringsprosessen. Dette har ofte resultert med språkblanding som for eksempel norwenglish, norsklish (norglish), svorsk, hinglish, spanglish, denglish.

Det at språk kommer bestandig i kontakt viser seg å ha potensiell innvirkning på språkendring og i tilfeller der språkkontakt mellom ulike språk er blitt gjenstand for undersøkelse blant språkforskere, referer man gjerne til kontaktlingvistikk, et område med fokus på hvordan kontakt mellom språkene har foregått og hvordan det har påvirket språkbruken over tid.

\section{Kodeveksling - begrepsavklaring}

I slutten av 1960-årene og begynnelsen av 1970-årene dukket det opp et splitter nytt forskningsområdet - kodeveksling, tilknyttet studien til den amerikanske lingvisten John Gumperz og den norske sosialantropologen Jan-Petter Blom. Deres studie av kodeveksling på Hemnesberget i Norge som ble publisert i 1972 i artikkelen Social meaning in linguistic structures: Code-switching in Norway omhandlet kodeveksling mellom ranamål og bokmål i Hemnesberget i Nord-Norge. I denne studien har disse framtredende forskere framstilt hvordan innbyggerne på Hemnesberget veksler mellom to varianter av norsk, den lokale dialekten på Hemnesberget i Nordland og et mer standardpreget talemål. Dialekten reflekterte en felles lokal identitet og ble brukt i personlige samtaler mellom de lokale, mens bokmål ble brukt utelukkende i mer formelle settinger som i undervisning eller i kirke. På bakgrunn av dette kan denne studien anses som forløperen til nytenkningen innen fagfeltet og dermed oppstarten til nyere forskning innenfor tospråklighet (Engedal 2015: 1).

For å kunne få helhetsbilde av teoretisk omfanget av fenomenet kodeveksling samt hva det innebærer, er det viktig å få med seg nokså bredt spekter av ulike betegnelser som hyppigst foregår i språklitteraturen. I den sammenheng forekommer definisjon av conversational code-switching presentert av John Gumperz veldig ofte: "The juxtaposition within the same speech exchange of passages of speech belonging to two different grammatical systems or subsystems" (Gumperz ifølge Ruud 2012: 3). Begrepsmessig sett, en slik formulering impliserer bruk av to ulike grammatiske systemer eller delsystemer innenfor en og samme samtale, 
eller også i en og samme ytring. I tillegg til dette, i forbindelse med kodeveksling nevnes også Florian Coulmas, som har introdusert en annen synsvinkel i analyse av begrepet:

Code-switching occurs where speakers are aware of the two varieties being distinct and are able to keep them apart even though they may not do so habitually and may not be conscious of every switch they make. Code-switching is regarded as a controllable strategy, differing from both ordinary borrowing of individual lexical items and unavoidable interference. (Coulmas ifølge Ellingsen 2015: 16-17)

Med dette, han har gitt innblikk i en, så å si, utvidet tolkning av fenomenet der han peker på det faktum at kodeveksling burde bli betraktet som både en bevisst og ubevisst handling med å framheve at vekslerne er bevisste på at det er to ulike varieteter, men at de ikke nødvendigvis er bevisste på hver veksling de foretar.

I sosiolingvistisk perspektiv er det enda flere ulike teoretiske begrepsavklaringer av kodeveksling avhengig av hvilket aspekt og hvilken kontekst den opptrer i. For eksempel, ifølge Engen og Kulbranstad, kodeveksling er et sosiolingvistisk begrep som kan betraktes både i bredere og smalere forstand. Ut ifra et bredt perspektiv, fenomenet innebærer bruk av to språk på hver sitt område, mens den snevrere definisjonen "avgrenser begrepet til å gjelde veksling mellom to eller flere språk innenfor en og samme samtale" (Engen og Kulbranstad ifølge Sandbakk, 2009: 29). Ytterligere, Røyneland definerer kodeveksling ved at "fleire ulike varietetar blir brukte innanfor ein og same samtale eller i vekslinga mellom samtalar" (Røyneland ifølge Sandbakk 2009: 29).

I den henseende et annet viktig kriteriet for bestemmelsen av kodevekslingen gjelder mengde ord dvs. språk som må være inkludert i samtale for at det kan regnes som kodeveksling. Akkurat denne uklarhet kan bidra til begrepsforvirring slik at kodeveksling i enkelte tilfeller forveksles med lån av ord.

I tillegg til det enda et betydningsfullt aspekt som ofte assosieres med kodeveksling er relatert til forskningsspørsmål som gjelder hvorvidt språkbrukere er bevisst på sine språkvalg og hva det har å si for deres veksling av kodene. Lanza er av den oppfatningen at ved kodeveksling veksler språkbrukeren mer eller mindre bevisst mellom sine to språk i samhandling med andre tospråklige. Konteksten er tospråklig og kodevekslingen "er ofte et språklig virkemiddel som kan brukes for å fremheve en tospråklig identitet” (Sandbakk ifølge Lanza, 2009: 30). Engen og Kulbrandstad på sin side mener at språkbrukere ikke behøver å være bevisste på at de alternerer mellom språkene eller hvorfor og at kodevekslingen kan tjene flere formål samtidig (Engen og Kulbrandstad ifølge Ruud 2012: 45). 
Forenklet sett kan fagtermen kodeveksling presiseres med å være veksling mellom ulike språklige koder, mens begrepet tar utgangspunkt i observasjoner av at språkbrukere som lever i skjæringspunktet mellom ulike språk eller varieteter, kan kombinere elementer fra disse. Imidlertid, for å få innsikt i altomfattende omfang av begrepet kodeveksling, er det nødvendig å se på leddene selve betegnelsen er satt sammen av - kode og veksling - som innebærer at noe står i opposisjon til noe annet (Van Ommeren 2016: 12). Det forutsetter videre at én kode lar seg skille fra andre koder, og det faktum at språkbrukere veksler, indikerer at de skifter systematisk mellom kvalitativt ulike system (Van Ommeren 2016: 12-13).

I den henseende analyseres det gjerne ordet kode og hva det som regel innebærer uavhengig av den faste konteksten den opptrer i. Nemlig, første referanser til begrepet kodet ofte knyttes til kommunikasjonsteknologien der bruk av kode ble opprinnelig registrert. Imidlertid, innenfor lingvistikken anses begrepet som en nøytral paraplybetegnelse for språk, dialekt, språksystem eller varietet. Denne tolkningen kan underbygges med faktum at Røyneland ser også på kode som "et helt språksystem som skiller seg fra andre språksystemer" i likhet med Engen og Kulbrandstad som også bruker en lignende definisjon og viser videre til at dette gjelder ulike språk og ulike språksystemer innefor samme språk som dialekter, sosiolekter osv. (Johnsen ifølge Røyneland 2015: 18). I forbindelse med forskningen utført innen psykolingvistikk på 1950- og 1960-tallet ble switch i det engelske begrepet code switching brukt med referanse til en elektrisk bryter som ble skrudd på når tospråklige vekslet språk.

Ifølge Jeff MacSwan, fikk begrepet code switching sitt fotfeste under et internasjonalt lingvistikk- og språkseminar i 1962 i tilknytning til Einar Haugen, selv om fenomenet for første gang ble nevnt langt tidligere $\mathrm{i}$ en anmeldelse av Uriel Weinreichs (1953) «Languages in contact» og deretter i Haugens (1956) «Bilingualism in the America». MacSwan mener imidlertid at fenomenet ble beskrevet så tidlig som i 1911, i et arbeid av Aurelio M. Espinosa (Engedal 2015: 1). Et viktig bidrag til forskning av overgangen fra switching code to code switching gav også Roman Jakobsen med sitt studie likhetstrekk mellom kodeveksling, informasjonteori og fonologiske systemer.

\section{Typer av kodeveksling}

Som det framgår av definisjoner lagt fram ovenfor i teksten, kan fenomenet tolkes som paraplybetegnelse for flere ulike variasjoner av kodeveksling dvs. ty- 
per og undertyper som forekommer tilnærmet like ofte i nettdiskursen. Her refereres det til den relevante framstillingen av Røyneland:

Det er vanleg å dele situasjonsintern kodeveksling inn i tre ulike typar: Det er for det første korte innskot, for det andre veksling mellom fraser eller taleturar, og for det tredje veksling innafor ein og same frase, setning eller ord. Slike samtaleinterne vekslingar er svært vanlege i fleirspråkleg kommunikasjon, og generelt kan ein seie at graden av kodeveksling aukar proposjonalt med graden av fleirspråkleg kompetanse. (Sandbakk ifølge Røyneland 2009: 29)

De tre typene av kodeveksling som Røyneland skjelner mellom, har Engen og Kulbrandstad konseptualisert som taggveksling (tag-switching), kodeveksling mellom setninger (intersentential switching) og setningsintern kodeveksling (intrasentential switching). Hovedskillet mellom disse tre typene i forhold til språkbruk og språkvalg reflekteres i det faktum at i første tilfelle, innskudsmåten ikke forutsetter noen gode språkkunnskaper ettersom det er bare fraser eller faste uttrykk i et annet språk som inkluderes i det språket som snakkes. Innskuddene er bare tillegg i setningen og ofte faste, formelliknende vendinger som for eksempel ikke sant eller jasså (Sandbakk ifølge Engen og Kulbrandstad 2009: 29-32). På den annen side, de to øvrige kodevekslingstyper impliserer større flerspråklig kompetanse for der hører kodevekslingen til selve meningen i ytringene.

I tillegg til det kan man også skille mellom situasjonsavhengig veksling og metaforisk veksling som tilskrives til forskere John Gumperz og Jan-Petter Blom. I den sammenheng, situasjonsavhengig veksling finner sted når man veksler mellom to koder alt etter situasjon, og gjerne motiveres av eksterne faktorer som miljø, tema og en endring i den sosiale situasjonen, mens metaforisk veksling refererer til indre faktorer og har sammenheng med individets oppfatning av seg selv i forhold til ytre faktorer og som regel kommer an på emne eller rolle (Mæhlum ifølge Staaby 2011: 89-91).

\section{Kodevekslingens funksjoner}

Et annet viktig aspekt ved en betraktelig del av kodevekslingsforskning i nyere faglitteratur består av å identifisere nøkkelfaktor som i vesentlig grad bidrar til forekomst av kodeveksling i en daglidagstale eller skrift. I den forbindelse, er sentralt forskningsspørsmål hvorvidt kodeveksling er situasjonsavhengig eller situasjonsuavhengig, dvs. om fenomenet er betinget $\mathrm{i}$ avgjørende grad av utenomspråklige (ekstralingvistiske) eller innenspråklige (intralingvistiske) forhold 
dvs. påvirkningsfaktorer. I den henseende, har Malik utarbeidet en innsiktsfull liste over ulike språkkontekster der kodeveksling oppstår med utgangspunkt i de mest dominerende årsakene som ligger bak dette fenomenet (Engedal ifølge Malik 2015: 4).

På den måten skiller det seg ut flere situasjoner, som for eksempel når taleren mangler et ord eller uttrykk eller et av språkene ikke har tilsvarende ord eller uttrykk. Det nevnes også et tilfelle av manglende terminologi som reflekteres i situasjon når taleren ikke er like kompetent $\mathrm{i}$ begge språk og når vedkommende ikke kan et begrep på begge språk. Enkelte ganger kan det også hende at taleren ikke gidder eller ikke orker finne på et tilsvarende ord, så tyr han til den enkleste løsningen. I enkelte tilfeller er det også påfallende at kodeveksling gjør seg gjeldende når taleren enten vil distansere seg eller nærme seg en bestemt gruppe og dermed markere tilhørighet. Den forekommer også i samtaleepisoder og gjerne inkluderer gjentakelser, eller vektlegger en sak, enten for å skape kontrast eller for å overraske, erte, gjengi eller utfordre en annens utsagn. Ut ifra stilistisk perspektiv brukes det som regel med hensikten for å krydre språket eller utvide språklige repertoar (Engedal 2015: 5). Konklusjonsmessig kan alle disse funksjoner klassifiseres innen noen av følgende kategorier: leksikalske mangler, tilgjengelighet, stilistiske funksjoner, vektlegging av et poeng, forklaring eller rådføring (Engedal 2015: 5-7). I et forsøk på å klargjøre hva annet ligger til grunn for språklig variasjon, dvs. kodeveksling, har sosialpsykologene Giles og Coupland utviklet en språklig tilpasningsteori eller akkomodasjonsteori (The Speech Accommodation Theory) for å fremme forståelse av mekanismene bak våre individuelle vekslinger i samtaler. Teorien har en stor relevans takket være sine sentrale funn som tyder på at to strategier - konvergering og divergering spiller avgjørende rolle angående vårt språkbruk og stilskifte alt etter hva vi som språkbrukere ønsker å oppnå: å nærme eller fjerne oss fra mottaker i samtalen. Ifølge teorien, når man konvergerer, prøver man å tilpasse seg mest mulig til den andre taleren med å «etterligne» hans språk ved å gjenbruke ordene eller uttrykkene hans. I motsatt tilfelle når man diverger, forsøker man å ta mest mulig avstand fra sin samtalepartner ved å utdype språklige forskjeller.

\section{Negativt syn på kodeveksling}

Ut ifra historisk perspektiv har holdninger til kodeveksling som sosiolingvistisk fenomen oscilert betraktelig i takt med dens tosidete tolkning som negativt og positivt språkavvik. Nemlig, selv om kodeveksling defineres som vanlig praksis 
når to- eller flerspråklige kommuniserer med hverandre, har forskingen vist at det å bruke flere språk i samme kommunikasjonssekvens gjerne blir vurdert negativt (Kulbrandstad 2015: 270). Tradisjonelt sett, ble kodeveksling sett på som konsekvens av en dårlig språkbeherskelse dvs. utilstrekkelig språkkompetanse og dermed var det stort sett negative forestillinger og negative konnotasjoner som var knyttet til fenomenet. Det negative synet på begrepet ble veldig fort den rådende oppfatningen som tolket fenomenet som hovedindikator på en manglende språklig kompetanse.

Det negative ryktet som kodeveksling hadde fått på seg, har Engen og Kulbranstad avlivet ved å påstod at kodeveksling kunne fylle mange funksjoner $\mathrm{i}$ språket, som å skape spesielle stilistiske effekter og å signalisere sosiale og psykologiske forhold knyttet til samtalepartnerne og relasjonene mellom dem (Engen og Kulbrandstad ifølge Ruud 2004: 22). Også ifølge Røyneland ble kodevekslingsstrategier brukt, bevisst eller ubevisst, for å skape en viss effekt eller for å signalisere noe om forholdet mellom samtalepartnere. Det kan være for å markere sosial, kulturell eller psykologisk nærhet eller distanse til samtalepartneren, eller for å signalisere en sammensatt sosial, kulturell eller etnisk identitet (Røyneland ifølge Van Ommeren 2016: 51). Dette ståstedet bidro merkbart til skift i synet på kodeveksling som ikke lenger ble oppfattet som slurv eller feil men tvert imot som en språkberikelse.

\section{Nettdiskurs, datamediert kommunikasjon og sosiale medier}

I det 21. århundre har internett etablert seg som suverent kommunikasjonsmedium for folk flest verden rundt og dermed blitt en enorm, sosial arena. Ifølge Leppänen og Peuronen (2012) er "internett dermed blitt en lingvistisk kontaktsone, hvor flerspråklige ressurser og repertoar kan vise seg å være en avgjørende kapital for vellykket kommunikasjon, handling og interaksjon" (Kvammen ifølge Leppänen \& Peuronen, 2014: 14).

I den sammenheng dukker det opp enda et beslektet fenomenet, dvs. begrep datamediert kommunikasjon som ifølge Susan Herrings (2007) benyttes for å referere til samtaler og kommunikasjon som foregår på nett, rettere bestemt $\mathrm{i}$ nettdiskurs (Kvammen 2014: 36). Med tanke på at datamediert kommunikasjon defineres som hybrid mellom tale og skrift blir denne formen for kommunikasjon ofte beskrevet som skrevet tale.

Et av hovedtrekkene av datamediert kommunikasjon i nettdiskurs er også bruk av såkalt nettspråk. Selv om nettspråket skrives, foregår det som sagt innen- 
for en muntlighetskonvensjon. Muntligheten bevares gjennom å bruke fyllord og gjentagelser (Lavik ifølge Tingstad 2009: 29). Det spontane muntlige språket kan gi seg utslag i mange nøleord som "eh", “øøh” og hm”, mens såkalte fyllord som "vel", "liksom", "på en måte" og "altså" er også resultat av det spontane, og fører til at det i det muntlige språket ofte kan være langt mellom innholdsordene (Lavik 2009: 29-30). Nettspråket bærer også preg av forkortelser og symboler som signaliserer følelser eller handlinger og kan dermed erstatte manglende kroppsspråk. Dette kan for eksempel være at man er glad, trist, eller må bryte chattingen fordi en må gå på toalettet (Lavik ifølge Liestøl 2007, Tingstad 2003). Språket eller sjargongen blir ofte referert til som Net-Lingo, og blir beskrevet som internetts språk-dictionary. Med andre ord, en ordbok med ord og begreper som brukes i forbindelse med internett, i tillegg en oversikt over alle smileys, kortformer for chat og e-poster, og andre hjelpemidler (Lavik ifølge Calishan 2009: 29).

Som tidligere nevnt, de aller fleste aktiviteter på internett innebærer interaksjon mellom mennesker gjennom sosiale medier. I denne spesifikke konteksten, "sosiale medier omfatter alt fra sosiale nettverkssider til blogger, videoblogger og hypertekstsamlinger men fellesnevneren er at internett eller nettbasert teknologi blir benyttet for å skape interaksjon mellom mennesker, i tillegg til at brukerne legger premissene for innholdet, i motsetning til en overordnet redaktør" (Lønrusten Rogstad 2015: 12). I tillegg til det "kjennetegnes sosiale medier av teknologisk blanding som inkluderer digitale medier (video, lyd, tekster, nett, tv) på den ene siden og informasjonsteknologi (datamaskin, telefon, internett) på den andre siden noe som skaper en form for mediekonvergens" (Lønrusten Rogstad 2015: 13). Nå om dagen brukes uttrykket sosiale medier nesten ensbetydende med sosiale nettverkssider.

\section{Analyse av kodeveksling på sosiale medier}

Den aller første undersøkelse av begrepet kodeveksling i nettdiskurs kan spores opp til studiet Codeswitching on the web: English and Jamaican Creole in E-Mail Communication (2006) av Lars Hinrichs som anses som foregangsmann på dette forskningsområdet. I sin analyse tok han utgangspunkt $\mathrm{i}$ kodeveksling $\mathrm{i}$ e-postsamtaler mellom tospråklige jamaicanere, med å fokusere på bruk av patois og engelsk for å oppnå spesifikke kommunikative mål. Han var spesielt opptatt av å finne ut i hvilken grad språkvalg var situasjonsbestemt, men også hvordan deltakerne gir kontekstuell informasjon gjennom kodevalg og hvordan de beskriver seg selv gjennom valg av kode. 
Hovedgrunnen til at kodeveksling mellom språkpar norsk-engelsk står sentralt i denne forskningen har sitt utgangspunkt i den dominerende status av engelsk i Norge innen flere domener. Språklig sett, Norge tilhører land som utgjør en integrerende del av den såkalte "voksende sirkelen" av land hvor engelsk blir brukt som fremmedspråk. Samtidig er det viktig å framheve at Norge aldri har vært kolonisert av noe engelsktalende land og ikke har engelsk som morsmål for flertall av befolkningen. Til tross for det er det stadig større fare for at det engelske språket oppnår hegemoniet innen nettdiskurs som følge av den helhetlige anglifisering av økende antall samfunnsområder. Også generelt sett har engelsk lenge blitt regnet som hovedspråket på internett, og engelskkunnskaper ble sett på som en uerstattelig forutsetning for nettbasert kommunikasjon.

I lyset av den framstilte problematikken, består den empiriske delen av studien hovedsakelig av undersøkelse av språkvalg og språkbruk blant en bestemt gruppe flerspråklige nordmenn i en alder fra 22 til 60 med fokus på kodeveksling mellom norsk og engelsk som forekommer i deres skriftlige kommunikasjon på nettet. I den sammenheng tar problemstillingen sikte på å belyse i hvilken grad og av hvilke grunner forekommer kodevekslingen mellom norsk og engelsk blant den målgruppen. Forskningen er basert på empirisk korpus bestående av et bestemt utvalg av statusoppdateringer, samtaletråder samt påfølgende kommentarfelt og reaksjoner på sosiale medier, i første rekke på Facebook, Twitter og Instagram hos norsktalende språkbrukere. Kartlegging av korpusmaterialet omfattet analyse av 39 innlegg som ble lagt ut på sosiale medier i løpet av 2021 i forbindelse med både aktuelle emner og verdensnyheter eller private samtaler og reaksjoner på tidsrelevante spørsmål eller dagligdags situasjoner. Undersøkelsen ble gjennomført på en avgrenset målgruppe bestående av 33 personer som oppfylte kriterier i forhold til engelskkunnskaper. For å unngå potensielle fallgruver i form av språklige forskjeller grunnet manglende ferdigheter i engelsk, hovedkriteriet var tilnærmet likt kompetansenivået på engelsk. Ettersom det var en forhåndsdefinert forutsetning ble det valgt ut nordmenn som hadde enten middels eller gjerne avanserte engelskkunnskaper. Demografiske kriterier som kjønn, inntekt, bosted eller yrke spilte ikke noen altfor stor rolle men det ble lagt vekt på at ingen grupper ble over eller underrepresentert. For å få innsikt i helhetsbildet av kodeveksling som foregår på internett ble det plukket ut nordmenn i aldersgruppen mellom 22 og 60 i et forsøk på å få et representativt utvalg som vil gjenspeile språkbruk og språkvaner blant forskjellige aldersgrupper. Hensikten var å fastslå de mest dominerende mekanismene og effektene av kodeveksling i tillegg til funksjoner med å analysere kommunikative og 
stilistiske aspektet av fenomenet. Foruten er formålet med analysen å adressere hvorvidt det finnes et spesifikt kodevekslingsmønster blant disse norsktalende språkbrukere.

Et påfallende trekk av det innsamlete materialet som danner grunnlag for denne analysen er at de aller fleste norsktalende språkbrukere som oftest tyr til engelske ord og uttrykk i samtaler som ellers foregår på norsk mens andre språk er nesten ikke-eksisterende i denne kommunikasjonen. Tatt i betraktning at nettdiskurs, og ikke minst sosiale medier er sterkt preget av engelskdominans, betraktes dermed denne typen kodevekslingen i kjølvannet av en typisk språkkontaktsituasjon. Med utgangspunkt i eksempler henvist i form av statusoppdateringer og samtaletråder fra nettsamfunn, bekreftes det samtidig påstanden at norsk er mer positiv til lånord fra engelsk enn de andre nordiske land er (Homme Holstad ifølge Sandøy 2012: 22) noe som nødvendigvis medfører en større grad av kodeveksling.

Med tanke på at analyse var gjennomført på de mest populære nettsamfunn men med forskjellige konsepter var det nødvendig å ta flere ulike faktor i betraktning. Det gjelder for eksempel granulitet eller antall tegn tillatt $i$ en melding som i enkelte tilfeller har vist seg å være avgjørende for lingvistiske valg som for eksempel på Twitter. Til forskjell fra Twitter, er det ingen begrensning på antall ord på Facebook og Instragram. Dessuten skiller disse sosiale medier seg fra hverandre også i den forstand at samtalen kan foregår både synkront og asynkront avhengig av diskursen som også kan ha en viss innvirkning på språk alternering hos brukere av sosiale medier i Norge.

På bakgrunn av det empiriske materialet, har denne undersøkelsen vist at nordmenn benytter seg veldig ofte med engelske ord og uttrykk i den norske konteksten. Alle 39 innlegg som utgjør dette korpusmaterialet inneholder en eller annen form for kodeveksling mellom norsk og engelsk som i mer eller mindre grad bidrar til formidling av ulike budskap typer. Enten det gjelder høyst kontroversielle politisk-relaterte saker (eksempler 29 og 31), tabubelagte temaer (eksempel 22 og 25), sedvanlige observasjoner (eksempler 17 og 20), refleksjoner om hverdagsaktiviteter (eksempler 1, 2, 4 og 6) eller verdensnyheter (eksempel 5 og 24). Det kan dermed sies at uavhengig av emne og anledning, har norske språkbrukere i mange tilfeller nedprioritert norske uttrykk og heller erstattet de med engelske ord som har mer klang.

Ytterligere ble det påvist at de gjør det både bevisst og ubevisst med forskjellige hensikter. Eksempler 1, 5, 9, 10, 11, 23, 24 og 30 tyder på et automatisk skifte til engelsk språk som gjør seg gjeldende spesielt hos yngre språkbrukere med 
tanke på at globale fenomener og den moderne «lingo» (binge-watching, hooking ghosting, clickbait, boomer, spoiler, bucket list, procrastination og forkortelser (OMG/FOMO) og så videre) har invadert norsk språk i sin opprinnelige form uten noen tilsvarende kopier og har blitt en del av den norske hverdagen. Dermed kan det sies at latskap og manglende terminologi er i enkelte tilfeller hovedgrunnen til kodeveksling på sosiale medier spesielt blant den unge generasjon $\mathrm{Z}$ og til en viss grad hos Milleniumgenerasjonen. Dette bidrar til at de automatisk veksler til engelsk som gjenkjennelsestegn med sine jevnaldrende og dermed bevisst prøver å markere tilhørighet til den gruppen som følger de mest populære globale trender og tendenser. Dette er ikke noe overraskende fenomen med tanke på at engelsk har en særstilling i Norge og betraktes heller som et andre språk enn et fremmedspråk (undervisningen i engelsk begynner så tidlig som på barneskolen). Det er akkurat derfor hyppigst bruk dvs. innslag av faste engelske uttrykk og ord ble observert først og fremst $\mathrm{i}$ forbindelse med den yngre generasjonen. Kodevekslingen gjorde seg mest gjeldende når samtalen dreide over mot de mest aktuelle internasjonale temaene, serier eller sport-relaterte saker (eksempler 1, 5, $9,24,28,32,34)$.

Utenom dette kan forekomst av kodeveksling tilknyttes til flere kommunikative funksjoner, for eksempel, spesifikt emnet eller emneskifte som innebærer den såkalte preferanserelatert kodeveksling der språkbrukeren prioriterer det ene språket framfor det andre (eksempler: 29 30, 31, 32, 34, 37 og 38). Preferansekodeveksling ble observert i ulike tilfeller enten det hadde med vaksiner eller internett handling å gjøre.

Ifølge Aarsæther kan det være flere grunner til at tospråklige viser preferanse for et språk, til tross for at kompetansen er god i det andre språket også. En forklaring kan være at en språkbruker generelt identifiserer seg mer med det ene språket, eller ønsker å snakke et bestemt språk i en gitt situasjon. (Aarsæther ifølge Ruud 2012: 47)

Blant lingvistiske og sosiale triggere som kan framprovosere kodeveksling på nettet er også identitetsmarkering (eksempler 2, 3, 9, 15/18). Kodeveksling kan gjerne fungere som en identitetsmarkør i tilfeller hvor språkbrukere kodeveksler enten for å vise tilhørighet eller tilknytning til et visst miljø eller gruppe (studenter, foreldre, influensere, travel-bloggere). Ifølge analyse kan kodeveksling også bli trigget av kommunikative funksjoner som inkluderer latterligjøring (eksempler 4, 12, 27, 35), språklek (eksempler 7, 8, 15), sitering med hensikten enten for å distansere seg eller nærme seg den bestemte gruppen (eksempler 29 og 32). Kodeveksling ble også observert i tilfeller når taleren framhevet ekstre- 
me værforhold - skuffende dårlige eller overraskende bra (eksempler 3, 17, 20), gratulerte med dagen (eksempel 12), gjentok noen ytringer for å framheve dem (eksempel 14), poengtere sin egen mening, enighet dvs. uenighet (eksempler 6, 11, 13, 30, 35) eller kritikk mot de ansvarlige (eksempler 31 og 38) og så videre. Av den grunn kan det også sies at kodevekslingen nettopp blir brukt som enten høflighetsstrategi eller konvergensstrategi for å opprettholde eller ivareta kontakten med den gruppen.

I tillegg til det kan det også nevnes at kodeveksling og kodevalg var hovedsakelig påvirket av tema så vel som formål med kommunikasjonen. Et annet viktig funn ved undersøkelsen var at i de aller fleste tilfeller kodevekslingen mellom norsk og engelsk på sosiale medier ikke skyldtes manglende kompetanse i det ene eller det andre språket. Tvert imot kunne forekomsten av kodeveksling forklares med det at enkelte følte at de kunne uttrykke seg mer presist på ett av de språkene og dermed formidle et klart og utvetydig budskap. I den sammenheng ble det også påvist at språkvalg og språklig variasjon kan begrunnes med både sosiale og lingvistiske faktorer grunnet kommunikative hensikter.

På grunnlag av den analysen av det innsamlete materialet er det mulig å si at alle tre typer av kodeveksling er blitt observert i den skriftlige korrespondanse blant norske språkbrukere på nettsamfunn. I samtlige innlegg ble det registrert variert bruk av både taggveksling, intersentential veksling i tillegg til intrasentential veksling. Tatt $\mathrm{i}$ betraktning at taggveksling ikke forutsetter noen avanserte engelskkunnskaper siden det er snakk om isolerte ord eller utrykk som nesten automatisk skytes inn i samtalen, er det ikke uforventet at flertall eksempler inneholder akkurat denne typen kodeveksling (totalt 22 innlegg - følgende eksempler fra Tabellen 1: 1, 7, 8, 9, 10, 11, 12, 13, 17, 18, 23, 25, 26, 27, 28, 29, $30,31,32,33,36,38)$. Sett i lyset av det faktum at bruk av intersentential og intrasentential type av kodeveksling er betinget av beherskelse av engelsk på et atskillig høyere nivå, ble det funnet langt færre eksempler. Det er totalt 11 innlegg som inneholder intersentential veksling (eksempler: 3, 4, 14, 15, 16, $19,20,21,22,37,39)$ mens intrasentential veksling er registrert i til sammen 6 innlegg (eksempler: 2, 5, 6, 24, 34, 35). Samtidig er det viktig å nevne at det er mange sammenfallende eksempler dvs. grensetilfeller som tilhører 2 ulike kategorier samtidig (taggveksling og intersentential veksling - eksempler: 10, $13,18,25,28,29,30,31,33)$. 
Tabellen 1. Kodeveksling på nettsamfunn

\begin{tabular}{|c|c|c|}
\hline Facebook & Twitter & Instagram \\
\hline $\begin{array}{l}\text { 1. Det var jaggu meg på } \\
\text { tide med nye episoder } \\
\text { av Game of Thrones, } \\
\text { netflix binge- watching } \\
\text { i kveld. Ingen spoilers, } \\
\text { takk. }\end{array}$ & $\begin{array}{l}\text { 2. Når eksamenstid } \\
\text { nærmer seg, } \\
\text { procrastination is at } \\
\text { its peak, her må man } \\
\text { skjerpe seg. }\end{array}$ & $\begin{array}{l}\text { 3. We have just settled } \\
\text { kids for tonight, blir det } \\
\text { regn i morra mon tro? }\end{array}$ \\
\hline $\begin{array}{l}\text { 4. Nettopp fått lappen. } \\
\text { Den er virkelig } \\
\text { priceless! } \\
\text { Drive safely! May your } \\
\text { common sense last } \\
\text { longer than your hair. }\end{array}$ & $\begin{array}{l}\text { 5. Rått av verdensrikeste } \\
\text { mann, Amazon- } \\
\text { grunnleggeren } \\
\text { Bezos å stikke til } \\
\text { verdensrommet, stay } \\
\text { tuned folkens. }\end{array}$ & $\begin{array}{l}\text { 6. Jeg er lissm forelska } \\
\text { i verdens rareste fyr, he } \\
\text { is driving me crazy....jeg } \\
\text { gruer meg han dude her } \\
\text { is such a bad influence... }\end{array}$ \\
\hline $\begin{array}{l}\text { 7. Hei alle, det ville } \\
\text { være freaking awesome } \\
\text { hvis dere ville like den } \\
\text { side her! } \\
\text { Du kommer ikke til å } \\
\text { angre - no promises no } \\
\text { regrets. }\end{array}$ & $\begin{array}{l}\text { 8. Dersom du mot all } \\
\text { formodning vurderer å } \\
\text { satse på kjøpet, kjøp på } \\
\text { en fast and safe way! }\end{array}$ & $\begin{array}{l}\text { 9. Noe som har blitt ..... } \\
\text { kom det jeg hadde sett } \\
\text { mye fram til, nemlig } \\
\text { fallskjermhopping som } \\
\text { lenge stod på bucket } \\
\text { lista. Det er fett! Epic } \\
\text { experience! }\end{array}$ \\
\hline $\begin{array}{l}\text { 10. Den store fæstn i } \\
\text { Svartebukta nærm seg } \\
\text { med stormskritt å vi } \\
\text { gled oss stort tel å rock } \\
\text { tel go musikk ilamme } \\
\text { dåkk. Join us! }\end{array}$ & $\begin{array}{l}\text { 11. Ho e faenme bra sjuk } \\
\text { ho der. Så uforutsigbar! } \\
\text { Helt gærn if u ask me. } \\
\text { Jeg ble ghostet igjen. }\end{array}$ & $\begin{array}{l}\text { 12. Gratulerer med de } 40 \\
\text { unge mann. Velkommen } \\
\text { i } 40 \text {-årsklubben. Takker } \\
\text { og bukker! Vi er } \\
\text { plutselig blitt ancient } \\
\text { history. }\end{array}$ \\
\hline $\begin{array}{l}\text { 13. Min fullstendinge } \\
\text { unbiased mening er at } \\
\text { Norge har den beste } \\
\text { nasjonalsangen. Am } \\
\text { I wrong? Kanskje har } \\
\text { jeg rett? Skriv gjerne } \\
\text { - strong opinions are } \\
\text { welcome! }\end{array}$ & $\begin{array}{l}\text { 14. Lutefiskfri andre } \\
\text { juledag dessverre. Vi får } \\
\text { gjenopplive tradisjonen } \\
\text { når jeg har bikket førti, } \\
\text { or maybe not. Maybe } \\
\text { not likevel. Hopefully, } \\
\text { u are having a blast in } \\
\text { Australia }\end{array}$ & $\begin{array}{l}\text { 15. Fire alarm at London } \\
\text { City Airport. Så langt så } \\
\text { godt. Heldig gris eller } \\
\text { lucky bastard? Kall det } \\
\text { hva du vil, enough is } \\
\text { enough. }\end{array}$ \\
\hline
\end{tabular}




\begin{tabular}{|c|c|c|}
\hline $\begin{array}{l}\text { 16. Håper du spiste } \\
\text { litt lutefisk og drakk } \\
\text { litt akevitt for meg, } \\
\text { otherwise I'd be } \\
\text { disappointed. }\end{array}$ & $\begin{array}{l}\text { 17. Tror aldri jeg har sett } \\
\text { folk i Oslo så lykkelige } \\
\text { på en mandags morgen } \\
\text { før. Nesten så folk } \\
\text { smiler til hverandre på } \\
\text { gata. } 10 \text { dager med sol - } \\
\text { skikkelig mood boost. }\end{array}$ & $\begin{array}{l}\text { 18. Da er det på tide å } \\
\text { snu snuten hjem. Det har } \\
\text { vært en lang tur, først } \\
\text { snartur til Tyskland, så } \\
\text { India, så en liten ferie i } \\
\text { Singapore/ Indonesia. } \\
\text { En liten touchdown } \\
\text { hjemme før det er ut } \\
\text { igjen til Vyborg på } \\
\text { Onsdag. Looking } \\
\text { forward to white xmas } \\
\text { at least. } \\
\end{array}$ \\
\hline $\begin{array}{l}\text { 19. Det som er } \\
\text { garantert er at ett av } \\
\text { disse to lagene vinner } \\
\text { Europa League. Fordel } \\
\text { Rosenborg. Let's see } \\
\text { what happens next. }\end{array}$ & $\begin{array}{l}\text { 20. London today. Norsk } \\
\text { vær derimot. Went off } \\
\text { from } 15 \text { degrees below } \\
\text { from } \mathrm{S} \text {, hope for better } \\
\text { days... }\end{array}$ & $\begin{array}{l}\text { 21. Not that bad at all! } \\
\text { 10. plass forrige uke } \\
\text { er nok det beste jeg } \\
\text { har så langt men her } \\
\text { må julematen trimmes } \\
\text { bort....Timingen er } \\
\text { upåklagelig. }\end{array}$ \\
\hline $\begin{array}{l}\text { 22. Alt dette for å } \\
\text { snakke med resett, eller } \\
\text { var det dokument? } \\
\text { Er sex fremdeles } \\
\text { tabuutfordrende ord? } \\
\text { Hurra for freedom of } \\
\text { speech. }\end{array}$ & $\begin{array}{l}\text { 23. Å snøflake seg til } \\
\text { sine } 15 \text { minutter in the } \\
\text { spotlight har aldri vært } \\
\text { enklere enn i clickbait- } \\
\text { alderen. Ja, ja sånn kan } \\
\text { det gå }\end{array}$ & $\begin{array}{l}\text { 24. OMG. Sex og } \\
\text { singelliv-oppfølgeren } \\
\text { «Just like that» r tilbake } \\
\text { på tv-skjermen. Hvorfor } \\
\text { r alle i ekstase? Den r ik } \\
\text { helt wow. Bitcher litt nå. } \\
\text { Ikke akkurat FOMO. } \\
\end{array}$ \\
\hline $\begin{array}{l}\text { 25. Tenker ofte det } \\
\text { er helt outrageous at } \\
\text { vi fortsatt lever i et } \\
\text { samfunn hvor det å } \\
\text { vise en helt vanlig } \\
\text { kvinnekropp har en } \\
\text { nyhetsverdi. Hvor crazy } \\
\text { går det an å være?! } \\
\text { Så menn kan ikke bli } \\
\text { utsatt for sexisme? } \\
\text { Jeg kan omtale menns } \\
\text { kroppsdeler så mye jeg } \\
\text { vil? }\end{array}$ & $\begin{array}{l}\text { 26. Blir en smule } \\
\text { forundret over hva } \\
\text { enkelte personligheter } \\
\text { slipper unna med i full } \\
\text { offentlighet, og i tillegg } \\
\text { vinner de priser for sin } \\
\text { arrogante og lavmålte } \\
\text { fremtredning, what a } \\
\text { paradox. }\end{array}$ & $\begin{array}{l}\text { 27. Prøver å zoome ut } \\
\text { kartet for å finne ut hvor } \\
\text { det er, men det er jo } \\
\text { faan ikke en dritt i mils } \\
\text { omkrets! } \mathrm{F}^{* * *} \text { this shit. } \\
\text { Jadajada, nå har } \\
\text { det klikka for P, gir } \\
\text { direksjoner til en stol.... }\end{array}$ \\
\hline
\end{tabular}




\begin{tabular}{|c|c|c|}
\hline $\begin{array}{l}\text { 28. Ååå, det er noe av } \\
\text { det dølleste jeg vet om, } \\
\text { når folk du har gått på } \\
\text { ungdomsskole med bare: } \\
\text { «Shit, du har forandret } \\
\text { deg». Ja, takk det skulle } \\
\text { bare mangle. Kjipt å } \\
\text { stagnere som 15-åring. } \\
\text { Give me a break. }\end{array}$ & $\begin{array}{l}\text { 29. Så, let me get this } \\
\text { straight. 1.dose vaksine } \\
\text { gir beskyttelse. } 2 . \text { dose } \\
\text { er bedre. Kombo er ikke } \\
\text { noe problem, kanskje } \\
\text { faktisk bedre. «Mix- } \\
\text { and-match» funker også } \\
\text { bra «according to the } \\
\text { WHO». }\end{array}$ & $\begin{array}{l}\text { 30.Kall meg gjerne } \\
\text { old-fashioned boomer } \\
\text { men jeg synes ikke } \\
\text { dette passer seg i en } \\
\text { lekebutikk. Generation } \\
\text { Z probably disagrees }\end{array}$ \\
\hline $\begin{array}{l}\text { 31. Tviler ikke. Denne } \\
\text { verden eksisterer ikke } \\
\text { om } 100 \text { år. Det er altfor } \\
\text { mange psykopatiske } \\
\text { statsledere i denne } \\
\text { verden. Det trengs } \\
\text { kun en som trykker på } \\
\text { knappen, og da sitter } \\
\text { ikke resten av verden og } \\
\text { venter. Da er det game } \\
\text { over. River of no return. }\end{array}$ & $\begin{array}{l}\text { 32. De samme } \\
\text { sjarlatanene som meldte } \\
\text { at det "kunne" bli } \\
\text { dritkaldt i julen melder } \\
\text { nå at det "kan" komme } \\
\text { mye snø i romjulen. } \\
\text { «Climate change or } \\
\text { climate crisis or climate } \\
\text { hoax is in full swing»? } \\
\text { Hvor får de disse løse } \\
\text { prognosene fra? Sikkert } \\
\text { fra de samme som er } \\
\text { skråsikre på hvordan } \\
\text { vær og klima blir om } \\
50 \text { år. }\end{array}$ & $\begin{array}{l}\text { 33. Jeg elsker furutrær, } \\
\text { men det blir mer } \\
\text { vanskelig å få tak i. Men } \\
\text { nå er vi to voksne, ett } \\
\text { barn og en hund, så nå } \\
\text { făr terrassepalmen lys på å. } \\
\text { i desember. Let it shine. }\end{array}$ \\
\hline $\begin{array}{l}\text { 34. Jeg er ufattelig } \\
\text { lei på grunn av ny } \\
\text { nedstegning. Joys } \\
\text { and pitfalls av } \\
\text { hjemmekontor, anyone? }\end{array}$ & $\begin{array}{l}\text { 35. Fravær av skjønn og } \\
\text { moral. } \\
\text { Sånn er det med } \\
\text { educated fools. Back off }\end{array}$ & $\begin{array}{l}\text { 36. Jeg har hooket med } \\
\text { en treningsnarkoman og } \\
\text { kuttet ut alt av sukker, } \\
\text { snop og søtsaker. Isn't it } \\
\text { ironic? }\end{array}$ \\
\hline $\begin{array}{l}\text { 37.Frivillig deltakelse. } \\
\text { End of story. Deres sted, } \\
\text { deres regler. Kleskoden } \\
\text { tjener formålet at } \\
\text { alle som dukker opp, } \\
\text { stiller like sårbare } \\
\text { og signaliserer at de } \\
\text { respekterer formålet } \\
\text { med eventen. Et ofte } \\
\text { helt nødvendig premiss } \\
\text { for trivselens del. }\end{array}$ & $\begin{array}{l}\text { 38. Mine støvler ble } \\
\text { bestilt fra ebay. Etter } \\
\text { mye frem og tilbake } \\
\text { trodde jeg de var } \\
\text { forsvunnet. Men i går } \\
\text { - altså en måned etter } \\
\text { bestilling lå de klare } \\
\text { til henting. Støvlene } \\
\text { var bestilt til et antrekk } \\
\text { jeg skulle bruke i } \\
\text { førjulstiden. Free } \\
\text { shipping sux, åpenbart. }\end{array}$ & $\begin{array}{l}\text { 39. For eit drama. } \\
\text { Eg har to raude slips. } \\
\text { Står mellom mormors } \\
\text { heimhekla eller pappas } \\
\text { skinnslips. Kva blir } \\
\text { juleslipset? Is there a } \\
\text { xmas dresscode? }\end{array}$ \\
\hline
\end{tabular}




\section{Konklusjon}

Generelt sett framstilles i denne oppgaven kodeveksling som et lingvistisk begrep, nærmere bestemt måten hvordan det tolkes, defineres og forklares i en spesifikk norsk kontekst innen nettdiskurs. Nemlig, hovedproblemstillingen i denne oppgaven omhandlet språklig kompleksitet av selve fenomenet og innebar undersøkelse av grunnårsaker, funksjoner og implikasjoner av dens økende forekomst innen datamediert kommunikasjon, først og fremst på sosiale medier i den norske konteksten. I dette konkrete tilfellet var fokus rettet mot kodeveksling mellom norsk og engelsk som forekommer hos norske språkbrukere innen nettdiskurs på de mest populære sosiale nettsamfunn som Facebook, Twitter og Instagram. I den henseende ble det stilt forskningsspørsmål som adresserte i hvilken grad og på hvilken måte fenomenet manifesterte seg i ulike situasjonsbestemte varianter med hensikten for å konseptualisere de mest dominerende språklige praksisene og tendensene, dvs. fastslå kodevekslingsmønster i nettdiskurs blant flerspråklige nordmenn. Den teoretiske tilnærmingen i oppgaven var basert på kontaktlingvistikk.

Med undersøkelsen ble det påvist at vekslingen mellom koder var en vanlig praksis blant flerspråklige nordmenn i nettdiskurs og at den forekom av en rekke grunner. Det ble også fastslått at norske språkbrukere ikke tyr til engelsk på grunn av mangelfull kompetanse men tvert imot, fordi de vil skape visse stilistiske effekter ved å benytte seg av denne alterneringen og dermed signalisere tilhørighet eller distanse fra en enkelt episode dvs. situasjon. Selv om det er mulig å kategorisere flere av kodevekslingene som forekommer, er det også mange som fremstår som spontane og ubevisste, og er dermed vanskeligere å klassifisere.

\section{REFERANSER}

Androutsopoulos 2006: J. Androutsopoulos, Introduction: Sociolinguistics and computer-mediated communication. Journal of Sociolinguistics 10(4), 419-438. [https://jannisandroutsopoulos.files.wordpress.com/2009/12/ jslx_10-4_intro.pdf]Nederst i skjemaet

Ellingsen 2015: E. Ellingsen, Det er vår måte å kommunisere på. En studie av språkbruk blant ungdom i flerspråklige miljø i Bergen. Masteroppgave, Institutt for lingvistiske, litterære og estetiske studie, Universitetet i Bergen, [https://bora.uib.no/bora-xmlui/bitstream/handle/1956/10399/Master\%20thesis_Ellen $\% 20 \mathrm{Marie} \% 20$ Ellingsen.pdf? sequence=4\&isAllowed $=\mathrm{y}]$ 
Engedal 2015: C. Engedal, Hvordan kommer kodeveksling mellom hindi og norsk til uttrykk blant unge, norsk-indere i Oslo? Masteroppgave, Universitetet i Oslo, [https://www.duo.uio.no/bitstream/handle/10852/45499/Masteroppgave Caterina-Engedal.pdf? sequence $=1$ \&isAllowed $=\mathrm{y}]$

Grøvli 2013: L. Grøvli, Lol wtf? Kodeveksling i norsk internettkommunikasjon. Masteroppgave, Universitetet i Oslo, [https://www.duo.uio.no/bitstream/handle/10852/37370/Grxvli-Master.pdf? sequence=2\&isAllowed=y]

Homme Holstad 2012: B. Homme Holstad, Språk $i$ et globalisert nceringsliv. Bruk av norsk og engelsk i maritim. Industrisektor. Masteroppgave, Universitetet i Oslo, [https://www.duo.uio.no/bitstream/handle/10852/35123/Homme master.pdf? sequence $=1$ \&isAllowed $=\mathrm{y}]$

Kulbrandstad 2015: L. Kulbrandstad, Språkholdninger. NOA norsk som andresprak $\cdot$ Argang 30 1-2/2015. Hogskolen i Hedmark, [http://ojs.novus.no/ index.php/NOA/article/view/1190/1180]

Kvamme Strømmen 2015: M. Kvamme Strømmen, Han leashet ikkje bot. No leash bot. Om bruken av engelsk språk hos eit knippe norske spelarar i ein norsk spelkonteks. Masteroppgåve ved Institutt for lingvistiske og nordiske studier, Universitetet i Oslo, [https://www.duo.uio.no/bitstream/handle/10852/45084/Strommen-Master.pdf?sequence=1]

Kvammen 2014: V. Kvammen, Kodeveksling i nettkommunikasjon. En studie av samisktalende nordmenns lingvistiske praksiser på internett. Masteroppgave, Høgskolen i Hedmark. [https://brage.inn.no/inn-xmlui/bitstream/handle/11250/217596/Kvammen.pdf?sequence $=1$ \&isAllowed=y]

Lavik 2009: M. Lavik, ....er logget på! En kvalitativ studie av hvordan ungdommer med dysleksi, opplever å "chatte" via Internett. Masteroppgave, Universitetet i Oslo. [https://www.duo.uio.no/bitstream/handle/10852/32167/ masteroppgavexkorrekturx-xKopi.pdf? sequence $=1$ \&isAllowed $=\mathrm{y}$ ]

Lønrusten Rogstad 2015: I. Lønrusten Rogstad, Tweets that matter. Politisk kommunikasjon $i$ et nytt medielandskap. Doktoravhandling, Universitetet i Oslo. Det samfunnsvitenskapelige fakultet, [https://www.duo.uio.no/bitstream/handle/10852/47528/phd-rogstad-duo.pdf?sequence=1\&isAllowed=y]

Ruud 2012: C. Ruud, Ja, det er våres gavespråk”. En undersøkelse av kodeveksling $i$ samtaler mellom voksne romer i norskopplaering og holdninger til slik veksling. Masteroppgave i nordiskdidaktikk, Det utdanningsvitenskapelige fakultet, Universitetet i Oslo, [https://www.duo.uio.no/bitstream/handle/10852/34115/RUUD _MASTER.pdf? sequence=2\&isAllowed=y] 
Sandbakk 2009: L. Sandbakk, Språk på flyttefot. En studie av språket til fem svensker bosatt i Norge med drøfting av kodeveksling og akkomodasjon. Doktoravhandling, Universitetet i Tromsø, Fakultet for humaniora, samfunnsvitenskap og lærerutdanning, [https://munin.uit.no/bitstream/handle $/ 10037 / 2380 /$ thesis.pdf? sequence $=2 \&$ isAllowed $=y$ ]

Staaby 2011: T. Staaby, Spillsnakk. Dataspillsamtalen som sjanger. Masteroppgave i nordisk, Institutt for lingvistiske, litterære og estetiske studier, Universitetet i Bergen, [https://bora.uib.no/bora-xmlui/bitstream/handle/1956/4960/82518868.pdf?sequence=1\&isAllowed=y ]

Van Ommeren 2016: R. Van Ommeren, Den flerstemmige språkbrukeren. En sosiolingvistisk studie av norske bidialektale, Doktoravhandling, Norges teknisk-naturvitenskapelige universitet, Institutt for språk og litteratur, [https:// ntnuopen.ntnu.no/ntnu-xmlui/bitstream/handle/11250/2428730/Rikke\%20 van $\% 200$ mmeren_PhD.pdf? sequence $=1$ ]

Vik Johnsen 2015: R. Vik Johnsen, Relativt bra norsk. En sosiolingvistisk studie av ungdommers forståelse av holdninger til norsk med utenlandsk aksent. Masteroppgave ved Institutt for lingvistiske og nordiske studier, Det humanistiske fakultet, Universitetet i Oslo. [https://www.duo.uio.no/bitstream/handle/10852/46878/Johnsen_2015 Relativt bra norsk.pdf?sequence=1\&isAllowed $=\mathrm{y}]$

\section{Kilder}

https://datareportal.com/reports/digital-2020-norway

https://www.ipsos.com/nb-no/ipsos-some-tracker-q321 


\section{Jovana Vurdelja}

\section{CODE-SWITCHING WITHIN INTERNET DISCOURSE IN NORWAY}

\section{Summary}

The principal aim of this study is to examine the concept of code-switching and its various manifestations modes within the internet communication in Norway, primarily in the context of social media. The main research hypothesis rests on the fact that internet discourse in Norway is increasingly exposed to the threat of domain loss posed by the growing hegemonic power of the English language penetrating all internet spheres as the lingua franca. Consequently, focus of the paper is set on the analysis of the code-switching for the Norwegian and English language pair in the group of Norwegians on the most popular social networks in Norway. The relevance, complexity and functions of this linguistic phenomenon are investigated within the theoretical and methodological framework of contact linguistics with special emphasis on the underlying triggers of the (co)-occurrence of specific patterns and contexts of code-switching within the discourse. Purpose of the study was to determine the most dominant mechanisms and effects in terms of stylistic and communicative aspects of the code alternation based on the specific language use.

Keywords: code-switching, Norway, social media, English, Internet discourse. 


\section{Јована Вурдеља}

\section{ПРЕКЉУЧИВАЊЕ КОДОВА У ОКВИРУ ИНТЕРНЕТ ДИСКУРСА У НОРВЕШКОЈ}

\section{Резиме}

Окосницу рада представља анализа лингвистичког феномена прекључивања кодова и начина на који се манифестује у оквиру интернет комуникације у Норвешкој, пре свега у контексту друштвених мрежа. Почетна хипотеза је постулирана у складу са чињеницом да је интернет дискурс у Норвешкој све више изложен ризику од растуће хегемоније енглеског језика који продире у све друштвене сфере и домене као lingua franca. $\mathrm{У}$ теоретско-методолошком оквиру контактне лингвистике, у фокусу рада је истраживање прекључивања кодова за језички пар норвешки и енглески на најпопуларнијим друштвеним мрежама у Норвешкој при чему се испитује релеватност, компексност и функције датог феномена са посебним освртом на главне окидаче и разлоге појављивања алтернације кодова међу групом Норвежана. Тиме се настоје утврдити доминантни механизми, обрасци као и стилистички/прагматички ефекти као резултат употребе одређеног језичког избора.

Кључне речи: прекључивање кодова, Норвешка, друштвене мреже, енглески, интернет дискурс. 